

From Vital and Health Statistics of the National Center for Health Statistics

Number $130 \cdot$ July 31,1987

\title{
Prevalence of Known Diabetes Among Black Americans
}

\author{
by Thomas F. Drury, Ph.D., and Anita L. Powell, Division of Epidemiology and Health Promotion
}

\section{Highlights}

In 1985, approximately 1.0 million black Americans had known diabetes-a rate of 35.9 per 1,000 population. Compared with 22 years ago, these 1985 estimates represent a substantial increase in both the number and the rate of black Americans with known diabetes. In 1963, only an estimated 228,000 black individuals had known diabetes, representing a rate of 11.7 known diabetics per 1,000 population.

Among black persons, known diabetes is relatively more frequent among older persons, females, the less educated, the formerly married, those living alone, and persons in families with low annual incomes. It is also proportionately more common among central city residents than among metropolitan area residents living outside a central city. Among black persons, those living in the West have the highest rate of known diabetes; those living in the Northeast, the lowest rate. Some of these sociodemographic variations in the rate of known diabetes among black persons are associated with the fact that certain categories have higher proportions of older persons, who are more likely than younger persons to have known diabetes. Differences in the rate of known diabetes among black individuals by marital status and living arrangement are largely explainable in these terms.

In both absolute and relative terms, the increase in the prevalence of known diabetes over the past 22 years has been greater for black persons than for white persons. From 1963 to 1985 , the number of white known diabetics increased by about $21 / 2$ times, and a twofold increase occurred in the rate for white persons. During that same period, there was a fourfold increase in the number of black persons with known diabetes, and a threefold increase occurred in the rate for black Americans.

Known diabetes is now relatively more common among black persons than it is among white persons. However, this overall difference in the relative likelihood of known diabetes was not always the case. From 1963 to 1968 , the overall rates of known diabetes among black and white persons were similar. Moreover, during the 1963-68 time period, when the relative frequency of known diabetes for the two racial groups was similar, there were offsetting trends among males and females. Over the 22-year period for which data are available, black females have consistently had higher observed rates of known diabetes than white females have had. From 1963 to 1967 , however, black males had lower overall rates than white males had. By 1975 (the second year after 1968 for which data are available) a crossover had occurred: The overall observed rate of known diabetes for black males was higher than that for white males.

The currently higher rate of known diabetes among black than white persons is pervasive. Across all sex, age, education, marital status, living arrangement, and regional categories and across most family income and location of residence categories of the population, black individuals are relatively more likely to have known diabetes than white persons are. Among black individuals 17 years of age and over, but not among white individuals in this age span, family income differences in the relative frequency of known diabetes are explained by educational attainment differentials that are associated with family income and the relative likelihood of having known diabetes.

\section{Background}

"Diabetes mellitus" is a term that refers to a heterogeneous group of disorders characterized by glucose intolerance. The National Health Interview Survey (NHIS) of the National Center for Health Statistics (NCHS) is designed to produce estimates of the number and characteristics of persons who have been told by a physician that they have diabetes. Estimates of the prevalence of known diabetes in the United States have been available from NHIS for more than 25 years, but it is only in the past 5 years that estimates of the prevalence of known diabetes specifically for black persons have been rou- 
tinely published. In 1960, NHIS statistics on the prevalence of known diabetes and associated disability and medical care were published for the period July 1957-June 1959. ${ }^{1}$ However, these statistics were shown only for the total population and for specific age and sex categories. In 1967, NHIS information on the prevalence of known diabetes by race was published for the first time. This information was based on data collected in a special supplement on known diabetes conducted from July 1964 through June $1965 .^{2}$ These data for fiscal year 1965 were not shown separately for black persons. They were classified only for white and all other races, a practice which continued in routine NHIS statistical reports through $1977 .{ }^{3}$ As a result, when the Workgroup on Epidemiology of the Committee on Scope and Impact of the National Commission on Diabetes published its report in $1977,{ }^{4}$ NHIS information on the prevalence of known diabetes among black Americans was notably absent. It was still lacking when the important compilation Diabetes Data: Compiled 1977 appeared in $1978 .^{5}$

NHIS information on the prevalence of known diabetes among black Americans apparently appeared for the first time in an official NCHS publication, Health: United States, $1981.6 \mathrm{In}$ an article published in this report, age-adjusted rates of known diabetes were shown for white and black individuals, and age-specific rates for white and black persons were shown by sex and educational attainment. A more detailed NCHS analysis of the role of obesity in explaining age-sex-race differentials in the relative frequency of known diabetes (which focused explicitly on black-white differences) was also subsequently published.?

Recognition of the important gaps that existed in the published literature with respect to the number and characteristics of black Americans with known diabetes gave rise to a concerted effort by NCHS staff to tabulate and compile available NHIS data on known diabetes for fiscal year 1963 (the earliest year for which NHIS data tapes still existed) through the current time period. The results of these computer analyses were made available to the National Diabetes Data Group of the National Institute of Diabetes, Digestive, and Kidney Diseases. This organization made excellent use of them, in conjunction with its own analyses of NCHS data tapes, in Diabetes in America. ${ }^{8}$ These data were also later used in the Report of the Secretary's Task Force on Black and Minority Health. ${ }^{9,10}$

This report represents an update and extension of NHIS data presented in Diabetes in America and is based on more recent and detailed data analyses. Whereas the prevalence of known diabetes among black Americans was shown through 1981 in Diabetes in America, data for 1982-85 are presented here. In Diabetes in America, rates of known diabetes were shown for white and black persons by sex and age for 197981; here, these rates are shown for an extensive set of sociodemographic categories. Age-adjusted rates by race and sex shown in Diabetes in America were based on 1976 NHIS data. Here, age-adjusted rates for 1979-81 are shown for white and black persons according to an extensive array of sociodemographic characteristics. Finally, in Diabetes in America, the trend for white and black individuals from 1963 through 1981 was shown for all ages; here, data for 1963-85 are shown by age and sex.

\section{Scope and objectives}

The data on the prevalence of known diabetes among black Americans shown in this publication have been selected to provide the information needed to answer the following kinds of questions. How many black Americans now have known diabetes? How does the rate of known diabetes vary among sociodemographic categories of black Americans? To what extent can variations in the rate of known diabetes among sociodemographic categories of black Americans be explained in terms of the older age composition of these groups? How different are the rates of known diabetes for black and white persons? To what extent are black-white differences in the relative frequency of known diabetes associated with differences in the age and social composition of black and white persons? How has the overall prevalence of known diabetes among black Americans changed over the past 22 years? How has the change in the prevalence of known diabetes among black Americans varied among sex and age categories of the black population? In what respects has the change in the prevalence of known diabetes among black persons differed from the change among white individuals?

\section{Source of data}

The data presented in this report were obtained through the National Health Interview Survey of the National Center for Health Statistics. The bulk of the data presented are based on three one-third subsamples of NHIS for which diabetes information was collected during the 1979-81 time period. ${ }^{11-13}$ However, individual-year data for the period 1963-68, as well as pooled data for 1982 through 1985, have also been used in describing the change in the prevalence of known diabetes among black Americans.

A brief description of the procedures used in NHIS is given in the Technical notes section of this report.

\section{Variations in prevalence among black Americans}

The average annual number of persons with known diabetes during 1979-81 by race, age, and selected sociodemographic characteristics is shown in table 1 . The number of persons with known diabetes per 1,000 population during 1979-81 is shown by these same characteristics in table 2 . Major variations in the relative frequency of known diabetes among black Americans, based on the data shown in table 2, are highlighted.

- During the period 1979-81, the relative frequency of known diabetes among black persons was 16 times higher for the group 65 years and over (131.7 per 1,000 population) than for the group under 45 years of age $(8.3$ per 1,000 persons).

- Among black individuals, known diabetes was also proportionately more common among females than among males, particularly in the group 45 years of age and over.

- The rate of known diabetes among black individuals with less than 12 years of education (78.3 per 1,000 popula- 
Table 1. Average annual number of persons with known diabetes, by age, race, and selected sociodemographic characteristics: United States, 1979-81

[Dato are based on annual one-third subsamples of National Health Interview Survey household interviews of the civilian noninstitutionalized population]

\begin{tabular}{|c|c|c|c|c|c|c|c|c|c|c|c|c|}
\hline \multirow[b]{2}{*}{ Characteristic } & \multicolumn{3}{|c|}{ All ages } & \multicolumn{3}{|c|}{ Under 45 years } & \multicolumn{3}{|c|}{$45-64$ years } & \multicolumn{3}{|c|}{65 years and over } \\
\hline & $\begin{array}{c}\text { All } \\
\text { races }^{1}\end{array}$ & White & Black & $\begin{array}{c}A / l \\
\text { races }^{1}\end{array}$ & White & Black & $\begin{array}{c}\text { All } \\
\text { races }^{i}\end{array}$ & White & Black & $\begin{array}{c}A / l \\
\text { races }^{1}\end{array}$ & White & Black \\
\hline & \multicolumn{12}{|c|}{ Number of persons with known diabetes in thousands } \\
\hline $\operatorname{Tatal}^{2} \ldots \ldots \ldots \ldots \ldots \ldots \ldots$ & 5.129 & 4,512 & 834 & 900 & 730 & 163 & 2,406 & 1,942 & 408 & 2,123 & 1,839 & 262 \\
\hline \multicolumn{13}{|l|}{ Sex } \\
\hline $\begin{array}{l}\text { Male. . . . . . } \ldots \ldots \ldots \ldots \ldots \ldots \\
\text { Female. . . . . } \ldots \ldots \ldots \ldots \ldots\end{array}$ & $\begin{array}{l}2,357 \\
3,072\end{array}$ & $\begin{array}{l}2,011 \\
2,501\end{array}$ & $\begin{array}{l}305 \\
529\end{array}$ & $\begin{array}{l}370 \\
530\end{array}$ & $\begin{array}{l}302 \\
429\end{array}$ & $\begin{array}{l}65 \\
99\end{array}$ & $\begin{array}{l}1,146 \\
1,259\end{array}$ & $\begin{array}{l}954 \\
988\end{array}$ & $\begin{array}{l}164 \\
244\end{array}$ & $\begin{array}{r}840 \\
1,283\end{array}$ & $\begin{array}{r}755 \\
1,084\end{array}$ & $\begin{array}{r}76 \\
186\end{array}$ \\
\hline \multicolumn{13}{|l|}{ Education of individual $\left.\right|^{3}$} \\
\hline $\begin{array}{l}\text { Less than } 12 \text { years } \ldots \ldots \ldots \ldots \ldots \\
12 \text { years or more............ }\end{array}$ & $\begin{array}{l}2,861 \\
2,435\end{array}$ & $\begin{array}{l}2,259 \\
2,143\end{array}$ & $\begin{array}{l}572 \\
240\end{array}$ & $\begin{array}{l}251 \\
586\end{array}$ & $\begin{array}{l}178 \\
497\end{array}$ & $\begin{array}{l}73 \\
82\end{array}$ & $\begin{array}{l}1,190 \\
1,191\end{array}$ & $\begin{array}{r}103 \\
1,018\end{array}$ & $\begin{array}{l}270 \\
133\end{array}$ & $\begin{array}{r}1,421 \\
659\end{array}$ & $\begin{array}{r}1,177 \\
627\end{array}$ & $\begin{array}{l}229 \\
* 24\end{array}$ \\
\hline \multicolumn{13}{|l|}{ Marital status ${ }^{3}$} \\
\hline $\begin{array}{l}\text { Married } \ldots \ldots \ldots \ldots \ldots \ldots \ldots \ldots \\
\text { Formerly married. } \ldots \ldots \ldots \ldots \ldots \ldots \\
\text { Never married } \ldots \ldots \ldots \ldots \ldots \ldots \ldots\end{array}$ & $\begin{array}{r}3,510 \\
1,520 \\
346\end{array}$ & $\begin{array}{r}3,030 \\
1,163 \\
273\end{array}$ & $\begin{array}{r}409 \\
348 \\
71\end{array}$ & $\begin{array}{l}573 \\
117 \\
158\end{array}$ & $\begin{array}{r}488 \\
70 \\
126\end{array}$ & $\begin{array}{r}79 \\
47 \\
* 32\end{array}$ & $\begin{array}{r}1.741 \\
554 \\
111\end{array}$ & $\begin{array}{r}1.487 \\
379 \\
76\end{array}$ & $\begin{array}{l}205 \\
171 \\
* 32\end{array}$ & $\begin{array}{r}1,196 \\
850 \\
77\end{array}$ & $\begin{array}{r}1,055 \\
714 \\
71\end{array}$ & $\begin{array}{r}125 \\
131 \\
* 6\end{array}$ \\
\hline \multicolumn{13}{|l|}{ Living arrangement } \\
\hline $\begin{array}{l}\text { With spouse } \ldots \ldots \ldots \ldots \ldots \ldots \ldots \\
\text { With relatives } \ldots \ldots \ldots \ldots \ldots \ldots \ldots \\
\text { With nonrelatives } \ldots \ldots \ldots \ldots \ldots \ldots \\
\text { Living alone. } \ldots \ldots \ldots \ldots \ldots \ldots \ldots\end{array}$ & $\begin{array}{r}3,464 \\
963 \\
89 \\
913\end{array}$ & $\begin{array}{r}3,000 \\
712 \\
63 \\
737\end{array}$ & $\begin{array}{l}394 \\
247 \\
* 26 \\
167\end{array}$ & $\begin{array}{r}565 \\
261 \\
* 26 \\
49\end{array}$ & $\begin{array}{l}483 \\
194 \\
* 20 \\
* 34\end{array}$ & $\begin{array}{r}76 \\
67 \\
* 5 \\
* 15\end{array}$ & $\begin{array}{r}1,720 \\
340 \\
* 30 \\
316\end{array}$ & $\begin{array}{r}1,476 \\
229 \\
* 19 \\
218\end{array}$ & $\begin{array}{r}195 \\
111 \\
* 11 \\
91\end{array}$ & $\begin{array}{r}1,179 \\
363 \\
* 33 \\
548\end{array}$ & $\begin{array}{r}1,041 \\
289 \\
* 24 \\
485\end{array}$ & $\begin{array}{r}123 \\
70 \\
* 9 \\
60\end{array}$ \\
\hline \multicolumn{13}{|l|}{ Family income $e^{4}$} \\
\hline $\begin{array}{l}\text { Less than } \$ 7,000 \ldots \ldots \ldots \ldots \ldots \ldots \\
\$ 7,000-\$ 9,999 \ldots \ldots \ldots \ldots \ldots \\
\$ 10,000-\$ 14,999 \ldots \ldots \ldots \ldots \\
\$ 15,000-\$ 24,999 \ldots \ldots \ldots \ldots \ldots \\
\$ 25,000 \text { or more. } \ldots \ldots \ldots \ldots \ldots \ldots\end{array}$ & $\begin{array}{r}1.453 \\
585 \\
828 \\
952 \\
1.190\end{array}$ & $\begin{array}{r}1.134 \\
519 \\
655 \\
833 \\
1,063\end{array}$ & $\begin{array}{r}312 \\
66 \\
150 \\
107 \\
99\end{array}$ & $\begin{array}{r}153 \\
69 \\
87 \\
242 \\
332\end{array}$ & $\begin{array}{r}116 \\
63 \\
59 \\
202 \\
307\end{array}$ & $\begin{array}{r}37 \\
* 6 \\
* 27 \\
40 \\
* 25\end{array}$ & $\begin{array}{l}470 \\
254 \\
396 \\
417 \\
643\end{array}$ & $\begin{array}{l}296 \\
207 \\
307 \\
378 \\
555\end{array}$ & $\begin{array}{r}166 \\
47 \\
77 \\
* 34 \\
60\end{array}$ & $\begin{array}{l}830 \\
263 \\
346 \\
293 \\
216\end{array}$ & $\begin{array}{l}722 \\
250 \\
289 \\
253 \\
201\end{array}$ & $\begin{array}{r}109 \\
* 13 \\
45 \\
* 33 \\
* 14\end{array}$ \\
\hline \multicolumn{13}{|l|}{ Location of residence } \\
\hline $\begin{array}{r}\text { SMSA }^{5} \ldots \ldots \ldots \ldots \\
\text { Central city } \ldots \ldots \ldots \ldots \ldots \ldots \ldots \\
\text { Outside central city. } \ldots \ldots \ldots \ldots \\
\text { Outside } \text { SMSA }^{5} \ldots \ldots \ldots \ldots \ldots \ldots \ldots\end{array}$ & $\begin{array}{l}3,604 \\
1,684 \\
1,920 \\
1,825\end{array}$ & $\begin{array}{l}2,896 \\
1,110 \\
1,786 \\
1,616\end{array}$ & $\begin{array}{l}638 \\
532 \\
107 \\
195\end{array}$ & $\begin{array}{l}613 \\
276 \\
338 \\
287\end{array}$ & $\begin{array}{l}478 \\
167 \\
311 \\
252\end{array}$ & $\begin{array}{l}131 \\
107 \\
* 24 \\
* 33\end{array}$ & $\begin{array}{r}1.611 \\
789 \\
872 \\
745\end{array}$ & $\begin{array}{r}1.291 \\
499 \\
791 \\
652\end{array}$ & $\begin{array}{r}322 \\
262 \\
60 \\
86\end{array}$ & $\begin{array}{r}1.330 \\
619 \\
711 \\
793\end{array}$ & $\begin{array}{r}1.128 \\
444 \\
684 \\
712\end{array}$ & $\begin{array}{l}186 \\
163 \\
* 23 \\
77\end{array}$ \\
\hline \multicolumn{13}{|l|}{ Geographic region } \\
\hline $\begin{array}{l}\text { Northeast. . . . . . } \ldots \ldots \ldots \ldots \\
\text { North Central. . . . } \ldots \ldots \ldots \ldots \ldots \\
\text { South. . . . . } \ldots \ldots \ldots \ldots \ldots \ldots \\
\text { West } \ldots \ldots \ldots \ldots \ldots \ldots \ldots \ldots \ldots \ldots\end{array}$ & $\begin{array}{r}1,205 \\
1,415 \\
1,981 \\
827\end{array}$ & $\begin{array}{r}1.068 \\
1.228 \\
1.516 \\
700\end{array}$ & $\begin{array}{r}135 \\
170 \\
448 \\
81\end{array}$ & $\begin{array}{l}181 \\
253 \\
309 \\
158\end{array}$ & $\begin{array}{l}161 \\
222 \\
215 \\
133\end{array}$ & $\begin{array}{r}* 19 \\
* 27 \\
95 \\
* 23\end{array}$ & $\begin{array}{l}533 \\
627 \\
914 \\
332\end{array}$ & $\begin{array}{l}451 \\
519 \\
710 \\
262\end{array}$ & $\begin{array}{r}80 \\
94 \\
191 \\
43\end{array}$ & $\begin{array}{l}491 \\
536 \\
758 \\
337\end{array}$ & $\begin{array}{l}456 \\
487 \\
591 \\
305\end{array}$ & $\begin{array}{r}36 \\
49 \\
163 \\
* 15\end{array}$ \\
\hline
\end{tabular}

IIncludes all other races not shown as separate categories.

"Includes unknown education of individual, marital status, and family income.

${ }^{3}$ Only persons 17 years and over are included in the category "all ages"; the category "under 45 years" comprises persons $17-44$ years of age.

${ }^{4}$ Data are for 1981 only because information on annual family income is available only for broad income categories and is technically difficult to adjust for inflation over the 3-year time period.

SMSA $=$ standard metropolitan statistical area.

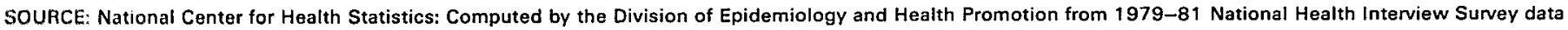
pravided by the Division of Health Interview Statistics.

tion) was three times higher than the rate among those with 12 or more years of education (26.2 per 1,000 population). The higher rate of known diabetes among less educated black Americans is partly explained by the older age composition of this group.

- Among black persons, the rate of known diabetes was 84.9 per 1,000 population for the formerly married but only 13.9 per 1,000 for the never married. However, this difference is largely attributable to the fact that the formerly married are considerably older than the never married, and increased age is strongly associated with a higher relative likelihood of known diabetes. Once age is taken into account, the difference between these two marital status categories is substantially reduced (table 3 ). Differences between the married and the other marital status categories are also substantially reduced by adjustment for variations in the age composition of these groups.

- The rate of known diabetes was about four times higher for black persons living alone (73.2 per 1,000 population) than for those living with their relatives $(15.9$ per 1,000$)$. Once again, the difference is largely explainable in terms of age differences between these groups (table 3 ). 
Table 2. Average annual number of persons with known diabetes per 1,000 population, by age, race, and selected sociodemographic characteristics: United States, 1979-81

[Data are based on annual one-third subsamples of National Health Interview Survey household interviews of the civilian noninstitutionalized population]

\begin{tabular}{|c|c|c|c|c|c|c|c|c|c|c|c|c|}
\hline \multirow[b]{2}{*}{ Characteristic } & \multicolumn{3}{|c|}{ All ages } & \multicolumn{3}{|c|}{ Under 45 years } & \multicolumn{3}{|c|}{$45-64$ years } & \multicolumn{3}{|c|}{65 vears and over } \\
\hline & $\begin{array}{c}\text { All } \\
\text { races }^{1}\end{array}$ & White & Black & $\begin{array}{c}A l l \\
\text { races }^{1}\end{array}$ & White & Black & $\begin{array}{c}A l l \\
\text { races }^{3}\end{array}$ & White & Black & $\begin{array}{c}A / I \\
\text { races }^{1}\end{array}$ & White & Black \\
\hline & \multicolumn{12}{|c|}{ Number of persons with known diabetes per 1,000 population } \\
\hline Total ${ }^{2}$. & 24.7 & 23.8 & 32.3 & 5.9 & 5.7 & 8.3 & 55.0 & 49.8 & 100.8 & 88.3 & 84.4 & 131.7 \\
\hline \multicolumn{13}{|l|}{ Sex } \\
\hline $\begin{array}{l}\text { Male } \ldots \ldots \ldots \ldots \ldots \ldots \ldots \\
\text { Female } \ldots \ldots \ldots \ldots \ldots \ldots \ldots\end{array}$ & $\begin{array}{l}22.2 \\
27.0\end{array}$ & $\begin{array}{l}21.9 \\
25.6\end{array}$ & $\begin{array}{l}25.5 \\
38.1\end{array}$ & $\begin{array}{l}4.9 \\
6.9\end{array}$ & $\begin{array}{l}4.7 \\
6.6\end{array}$ & $\begin{array}{l}6.9 \\
9.4\end{array}$ & $\begin{array}{l}55.0 \\
55.1\end{array}$ & $\begin{array}{l}51.1 \\
48.7\end{array}$ & $\begin{array}{r}89.7 \\
109.9\end{array}$ & $\begin{array}{l}85.1 \\
90.6\end{array}$ & $\begin{array}{l}84.5 \\
84.3\end{array}$ & $\begin{array}{r}93.8 \\
158.0\end{array}$ \\
\hline \multicolumn{13}{|l|}{ Education of individual ${ }^{3}$} \\
\hline $\begin{array}{l}\text { Less than } 12 \text { years } \ldots \ldots \ldots \ldots \\
12 \text { years or more......... }\end{array}$ & $\begin{array}{l}58.1 \\
22.2\end{array}$ & $\begin{array}{l}55.0 \\
21.8\end{array}$ & $\begin{array}{l}78.3 \\
26.2\end{array}$ & $\begin{array}{r}12.2 \\
8.1\end{array}$ & $\begin{array}{r}10.7 \\
7.9\end{array}$ & $\begin{array}{l}21.1 \\
11.3\end{array}$ & $\begin{array}{l}78.9 \\
42.6\end{array}$ & $\begin{array}{l}72.1 \\
39.4\end{array}$ & $\begin{array}{r}116.9 \\
83.3\end{array}$ & $\begin{array}{r}104.8 \\
67.6\end{array}$ & $\begin{array}{l}99.0 \\
67.4\end{array}$ & $\begin{array}{l}148.6 \\
{ }^{*} 70.4\end{array}$ \\
\hline \multicolumn{13}{|l|}{ Marital status ${ }^{3}$} \\
\hline $\begin{array}{l}\text { Married. . . . . . . . } \ldots \ldots \ldots \\
\text { Formerly married } \ldots \ldots \ldots \ldots \\
\text { Never married } \ldots \ldots \ldots \ldots \ldots\end{array}$ & $\begin{array}{l}34.0 \\
61.6 \\
10.4\end{array}$ & $\begin{array}{r}32.4 \\
57.3 \\
9.9\end{array}$ & $\begin{array}{l}52.8 \\
84.9 \\
13.9\end{array}$ & $\begin{array}{r}10.3 \\
14.3 \\
5.3\end{array}$ & $\begin{array}{r}9.8 \\
10.9 \\
5.1\end{array}$ & $\begin{array}{l}17.4 \\
28.2 \\
* 6.9\end{array}$ & $\begin{array}{l}50.5 \\
77.3 \\
53.8\end{array}$ & $\begin{array}{l}47.1 \\
66.5 \\
44.2\end{array}$ & $\begin{array}{r}86.3 \\
124.4 \\
* 106.5\end{array}$ & $\begin{array}{l}89.6 \\
91.0 \\
57.1\end{array}$ & $\begin{array}{l}85.2 \\
87.4 \\
55.8\end{array}$ & $\begin{array}{l}149.3 \\
120.9 \\
* 88.5\end{array}$ \\
\hline \multicolumn{13}{|l|}{ Living arrangement } \\
\hline $\begin{array}{l}\text { With spouse } \ldots \ldots \ldots \ldots \ldots \\
\text { With relatives } \ldots \ldots \ldots \ldots \\
\text { With nonrelatives } \ldots \ldots \ldots \\
\text { Living alone........ }\end{array}$ & $\begin{array}{l}33.9 \\
10.3 \\
18.3 \\
47.2\end{array}$ & $\begin{array}{r}32.3 \\
9.4 \\
14.8 \\
43.8\end{array}$ & $\begin{array}{r}52.4 \\
15.9 \\
* 54.3 \\
73.2\end{array}$ & $\begin{array}{r}10.3 \\
3.1 \\
* 6.3 \\
6.2\end{array}$ & $\begin{array}{r}9.8 \\
2.8 \\
* 5.6 \\
{ }^{*} 5.0\end{array}$ & $\begin{array}{r}17.3 \\
4.8 \\
* 16.8 \\
* 15.0\end{array}$ & $\begin{array}{r}50.3 \\
75.5 \\
* 60.9 \\
69.6\end{array}$ & $\begin{array}{r}47.1 \\
67.0 \\
* 49.6 \\
56.7\end{array}$ & $\begin{array}{r}83.9 \\
113.4 \\
* 106.0 \\
141.5\end{array}$ & $\begin{array}{r}89.8 \\
100.4 \\
* 111.3 \\
78.5\end{array}$ & $\begin{array}{r}85.3 \\
95.9 \\
* 94.8 \\
76.7\end{array}$ & $\begin{array}{r}154.0 \\
133.0 \\
* 201.7 \\
97.0\end{array}$ \\
\hline \multicolumn{13}{|l|}{ Family income $e^{4}$} \\
\hline $\begin{array}{l}\text { Less than } \$ 7,000 \ldots \ldots \ldots \ldots \\
\$ 7,000-\$ 9,999 \ldots \ldots \ldots \ldots \ldots \\
\$ 10,000-\$ 14,999 \ldots \ldots \ldots \\
\$ 15,000-\$ 24,999 \ldots \ldots \ldots \\
\$ 25,000 \text { or more } \ldots \ldots \ldots \ldots\end{array}$ & $\begin{array}{l}44.5 \\
33.7 \\
24.6 \\
17.2 \\
16.4\end{array}$ & $\begin{array}{l}45.5 \\
35.0 \\
24.1 \\
16.6 \\
16.0\end{array}$ & $\begin{array}{l}42.8 \\
30.4 \\
29.1 \\
22.5 \\
23.2\end{array}$ & $\begin{array}{l}8.1 \\
6.2 \\
4.7 \\
5.8 \\
5.8\end{array}$ & $\begin{array}{l}7.9 \\
5.5 \\
4.8 \\
5.5 \\
5.8\end{array}$ & $\begin{array}{r}9.5 \\
* 9.9 \\
* 5.1 \\
8.9 \\
* 6.9\end{array}$ & $\begin{array}{l}97.3 \\
76.2 \\
67.3 \\
45.8 \\
35.0\end{array}$ & $\begin{array}{l}85.0 \\
74.7 \\
62.0 \\
42.3 \\
33.2\end{array}$ & $\begin{array}{r}135.7 \\
96.6 \\
110.5 \\
{ }^{*} 86.1 \\
63.5\end{array}$ & $\begin{array}{r}100.8 \\
83.4 \\
84.7 \\
79.4 \\
99.7\end{array}$ & $\begin{array}{l}96.9 \\
81.6 \\
79.2 \\
76.3 \\
96.3\end{array}$ & $\begin{array}{r}126.9 \\
* 113.8 \\
174.2 \\
* 155.4 \\
* 234.6\end{array}$ \\
\hline \multicolumn{13}{|l|}{ Location of residence } \\
\hline $\begin{array}{r}\text { SMSA }^{5} \ldots \ldots \ldots \ldots \ldots \ldots \\
\quad \text { Central city. } \ldots \ldots \ldots \ldots \ldots \\
\text { Outside central city } \ldots \ldots \ldots \\
\text { Outside SMSA }{ }^{5} \ldots \ldots \ldots \ldots\end{array}$ & $\begin{array}{l}24.0 \\
27.9 \\
21.4 \\
26.2\end{array}$ & $\begin{array}{l}22.9 \\
25.1 \\
21.7 \\
25.6\end{array}$ & $\begin{array}{l}32.0 \\
37.0 \\
19.2 \\
33.2\end{array}$ & $\begin{array}{l}5.9 \\
6.7 \\
5.3 \\
6.1\end{array}$ & $\begin{array}{l}5.5 \\
5.8 \\
5.4 \\
5.9\end{array}$ & $\begin{array}{l}8.5 \\
9.8 \\
* 5.3 \\
* 7.5\end{array}$ & $\begin{array}{l}55.4 \\
65.3 \\
48.6 \\
54.3\end{array}$ & $\begin{array}{l}49.0 \\
53.1 \\
46.8 \\
51.6\end{array}$ & $\begin{array}{r}105.2 \\
112.4 \\
82.3 \\
87.0\end{array}$ & $\begin{array}{l}85.5 \\
86.4 \\
84.7 \\
93.5\end{array}$ & $\begin{array}{l}81.2 \\
75.4 \\
85.4 \\
90.0\end{array}$ & $\begin{array}{l}128.2 \\
142.0 \\
75.5 \\
141.0\end{array}$ \\
\hline \multicolumn{13}{|l|}{ Geographic region } \\
\hline 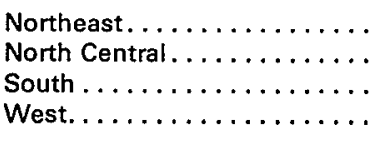 & $\begin{array}{l}25.0 \\
24.4 \\
27.5 \\
20.0\end{array}$ & $\begin{array}{l}24.8 \\
23.5 \\
26.3 \\
19.2\end{array}$ & $\begin{array}{l}28.3 \\
32.7 \\
33.0 \\
35.5\end{array}$ & $\begin{array}{l}5.6 \\
6.3 \\
6.2 \\
5.4\end{array}$ & $\begin{array}{l}5.7 \\
6.2 \\
5.5 \\
5.2\end{array}$ & $\begin{array}{r}{ }^{*} 5.2 \\
{ }^{*} 6.7 \\
9.2 \\
{ }^{*} 13.0\end{array}$ & $\begin{array}{l}52.1 \\
54.7 \\
64.5 \\
42.3\end{array}$ & $\begin{array}{l}48.0 \\
49.0 \\
59.4 \\
37.3\end{array}$ & $\begin{array}{r}103.6 \\
119.8 \\
90.2 \\
114.6\end{array}$ & $\begin{array}{l}85.6 \\
85.3 \\
97.0 \\
80.6\end{array}$ & $\begin{array}{l}83.6 \\
82.6 \\
89.6 \\
79.2\end{array}$ & $\begin{array}{r}131.4 \\
131.6 \\
135.5 \\
* 101.7\end{array}$ \\
\hline
\end{tabular}

${ }^{1}$ Includes all other races not shown as separate categories.

Includes unknown education of individual, marital status, and family income.

"Only persons 17 years and over are included in the category "all ages"; the category "under 45 years" comprises persons $17-44$ years of age.

${ }^{4}$ Data are for 1981 only because information on annual family income is available only for broad income categories and is technically difficult to adjust for inflation over the 3-year time period.

${ }^{5}$ SMSA $=$ standard metropolitan statistical area.

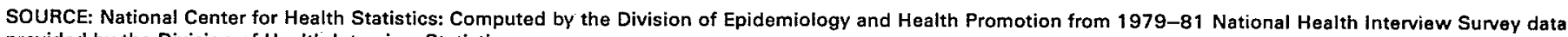
provided by the Division of Health Interview Statistics.

- The prevalence of known diabetes per 1,000 black individuals was almost twice as high for persons in families with annual incomes of less than $\$ 7,000$ (42.8 per 1,000) than for persons in families with annual incomes of $\$ 25,000$ or more $(23.2$ per 1,000$)$.

- Known diabetes was relatively more prevalent among black central city residents $(37.0$ per 1,000$)$ than among black metropolitan area residents living outside the central city (19.2 per 1,000). This is particularly the case among black persons 45 years of age and over (table 2).

\section{Black-white differences in prevalence}

During the period 1979-81, the rate of known diabetes among black persons, 32.3 per 1,000 population, was 1.4 times higher than the rate among white persons was, 23.8 per 1,000 (table 2). In each of the three age categories shown in table 2 , the ratio between the rates of diabetes for black and white persons is at least 1.4, and it is about 2.0 among persons 45 64 years of age. Indeed, were it not for the fact that the black population is younger than the white population, the black- 
Table 3. Age-adjusted average annual number of persons with known diabetes per 1,000 population and associated standard errors, by race and selected sociodemographic characteristics: United States, 1979-81

[Data are based on annual one-third subsamples of National Health Interview Survey household interviews of the civilian noninstitutionalized population]

\begin{tabular}{|c|c|c|c|c|c|c|}
\hline Characteristic & $\begin{array}{l}\text { Al/ } \\
\text { races }^{1}\end{array}$ & White & Black & $\begin{array}{l}\text { All } \\
\text { races }\end{array}$ & White & Black \\
\hline & \multicolumn{3}{|c|}{$\begin{array}{l}\text { Age-adjusted }{ }^{2} \text { number of } \\
\text { persons with known diabetes } \\
\text { per } 1,000 \text { population }\end{array}$} & \multicolumn{3}{|c|}{ Standard error ${ }^{3,4}$} \\
\hline Total $^{5} \ldots \ldots \ldots \ldots \ldots \ldots \ldots \ldots \ldots \ldots \ldots \ldots \ldots \ldots$ & 24.8 & 23.1 & 40.2 & 0.5 & 0.5 & 2.1 \\
\hline \multicolumn{7}{|l|}{ Sex } \\
\hline $\begin{array}{l}\text { Male } \ldots \ldots \ldots \ldots \ldots \ldots \ldots \ldots \ldots \ldots \ldots \ldots \ldots \ldots \ldots \ldots \ldots \ldots \ldots \ldots \ldots \ldots \ldots \ldots \ldots \ldots \ldots \ldots \ldots \ldots \ldots \ldots \ldots \\
\text { Fomale } \ldots \ldots \ldots \ldots \ldots \ldots \ldots \ldots\end{array}$ & $\begin{array}{l}23.7 \\
25.7\end{array}$ & $\begin{array}{l}22.7 \\
23.6\end{array}$ & $\begin{array}{l}33.0 \\
45.8\end{array}$ & $\begin{array}{l}0.6 \\
0.6\end{array}$ & $\begin{array}{l}0.7 \\
0.7\end{array}$ & $\begin{array}{l}3.0 \\
2.7\end{array}$ \\
\hline \multicolumn{7}{|l|}{ Education of individual 6} \\
\hline $\begin{array}{l}\text { Less than } 12 \text { years. } \ldots \ldots \ldots \ldots \ldots \ldots \ldots \ldots \ldots \ldots \ldots \ldots \ldots \ldots \ldots \ldots \ldots \ldots \ldots \ldots \ldots \ldots \ldots \ldots \ldots \ldots \ldots \ldots \ldots \ldots \ldots \ldots \\
12 \text { years or more } \ldots \ldots \ldots \ldots \ldots \ldots \ldots \ldots\end{array}$ & $\begin{array}{l}44.1 \\
26.4\end{array}$ & $\begin{array}{l}40.5 \\
25.3\end{array}$ & $\begin{array}{l}66.1 \\
39.6\end{array}$ & $\begin{array}{l}1.1 \\
0.7\end{array}$ & $\begin{array}{l}1.3 \\
0.7\end{array}$ & $\begin{array}{l}4.5 \\
4.0\end{array}$ \\
\hline \multicolumn{7}{|l|}{ Marital status 6} \\
\hline 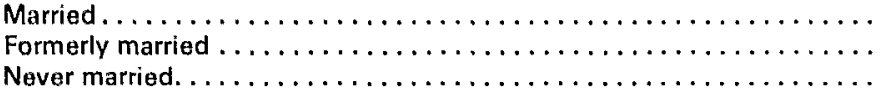 & $\begin{array}{l}33.0 \\
42.8 \\
26.1\end{array}$ & $\begin{array}{l}31.2 \\
37.4 \\
23.3\end{array}$ & $\begin{array}{l}55.7 \\
68.1 \\
46.0\end{array}$ & $\begin{array}{l}0.8 \\
1.7 \\
2.6\end{array}$ & $\begin{array}{l}0.8 \\
1.8 \\
2.7\end{array}$ & $\begin{array}{r}4.0 \\
5.6 \\
11.2\end{array}$ \\
\hline \multicolumn{7}{|l|}{ Living arrangement } \\
\hline 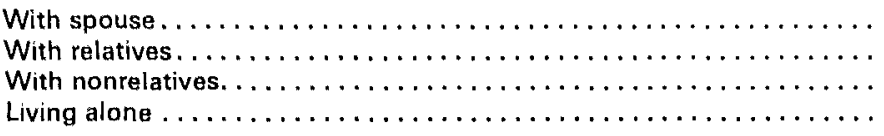 & $\begin{array}{l}27.0 \\
28.2 \\
28.7 \\
26.8\end{array}$ & $\begin{array}{l}25.5 \\
25.8 \\
24.1 \\
23.2\end{array}$ & $\begin{array}{l}45.6 \\
40.5 \\
54.9 \\
49.2\end{array}$ & $\begin{array}{l}0.6 \\
1.4 \\
5.3 \\
1.5\end{array}$ & $\begin{array}{l}0.7 \\
1.4 \\
4.9 \\
1.6\end{array}$ & $\begin{array}{r}3.4 \\
4.6 \\
16.0 \\
5.4\end{array}$ \\
\hline \multicolumn{7}{|l|}{ Family income ${ }^{7}$} \\
\hline 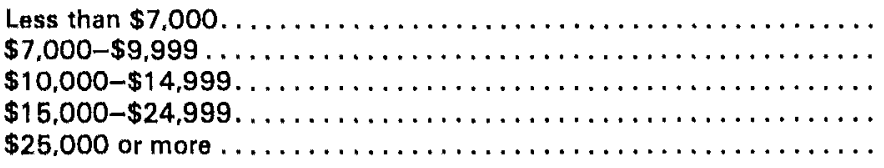 & $\begin{array}{l}37.5 \\
29.6 \\
25.8 \\
23.6 \\
20.7\end{array}$ & $\begin{array}{l}34.7 \\
29.5 \\
22.8 \\
22.0 \\
20.0\end{array}$ & $\begin{array}{l}48.2 \\
34.7 \\
52.5 \\
58.1 \\
40.4\end{array}$ & $\begin{array}{l}2.4 \\
3.4 \\
2.7 \\
2.0 \\
2.0\end{array}$ & $\begin{array}{l}2.9 \\
3.7 \\
2.7 \\
2.0 \\
2.1\end{array}$ & $\begin{array}{r}6.3 \\
9.5 \\
10.0 \\
13.8 \\
18.8\end{array}$ \\
\hline \multicolumn{7}{|l|}{ Location of residence } \\
\hline 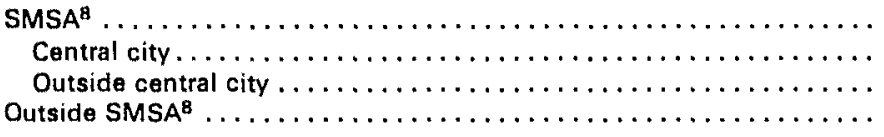 & $\begin{array}{l}24.5 \\
27.1 \\
22.7 \\
25.3\end{array}$ & $\begin{array}{l}22.5 \\
22.8 \\
22.5 \\
24.3\end{array}$ & $\begin{array}{l}40.9 \\
44.8 \\
28.4 \\
38.0\end{array}$ & $\begin{array}{l}0.5 \\
0.9 \\
0.7 \\
0.9\end{array}$ & $\begin{array}{l}0.6 \\
1.1 \\
0.8 \\
0.9\end{array}$ & $\begin{array}{l}2.4 \\
2.6 \\
4.3 \\
4.4\end{array}$ \\
\hline \multicolumn{7}{|l|}{ Geographic region } \\
\hline 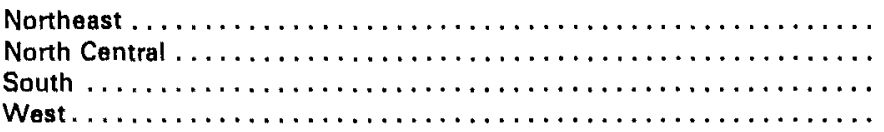 & $\begin{array}{l}23.6 \\
24.6 \\
27.8 \\
21.0\end{array}$ & $\begin{array}{l}22.7 \\
23.1 \\
25.5 \\
19.7\end{array}$ & $\begin{array}{l}38.7 \\
42.9 \\
39.2 \\
43.0\end{array}$ & $\begin{array}{l}0.9 \\
0.7 \\
1.0 \\
1.1\end{array}$ & $\begin{array}{l}1.0 \\
0.8 \\
1.0 \\
1.2\end{array}$ & $\begin{array}{l}5.8 \\
3.1 \\
3.1 \\
5.3\end{array}$ \\
\hline
\end{tabular}

1 Includes all other races not shown as separate categories.

${ }_{2}^{2}$ ge adjusted by the direct method to the 1979-81 civilian noninstitutionalized population using 3 age groups.

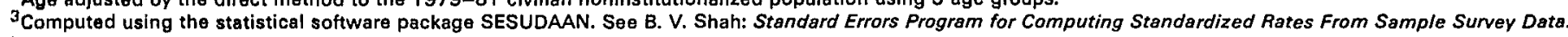
Research Triangle Park, N.C. Research Triangle Institute, Apr. 1981.

495-percent confidence intervals for the rates shown can be obtained by multiplying the standard error by 1.96 and adding and subtracting the obtained value from the observed rate.

EIncludes unknown education of individual, marital status, and family income.

"Only persons 17 years and over are included in the category "all ages"; the category "under 45 years" comprises persons $17-44$ years of age.

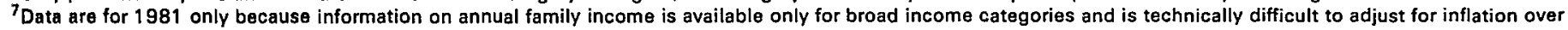
the 3-year time period.

${ }^{8}$ SMSA = standard metropolitan statistical area.

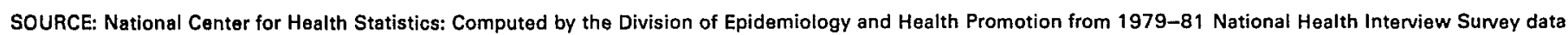
provided by the Division of Health Interview Statistics.

white differences would be even larger than observed. This is easily seen by comparing the differences between the unadjusted rates for black and white persons in table 2 with the differences between the age-adjusted rates in table 3 .

The black-white difference in the relative frequency of known diabetes is not explained by variations in the social composition of the black and white populations. The greater relative likelihood of known diabetes among black individuals is pervasive. With the exception of metropolitan area residents outside the central city and persons in families with annual incomes of less than $\$ 10,000$, irrespective of the category examined, black individuals have a higher rate of known diabetes than white persons have (table 2). This is true even when black-white differences are viewed simultaneously by educa- 
tion and geographic characteristics (as in table 4) or by education and income (as in the figure).

Also highlighted in the figure is the fact that family income differences in the relative frequency of known diabetes among black persons 17 years of age and over, but not among similarly aged white individuals, are largely explained by differences in educational attainment. When education is controlled (by comparing family income variations in the relative frequency of known diabetes within educational categories), there is no relationship between family income and the rate of known diabetes among black persons 17 years and over. Among white individuals in this same age span, however, the relative frequency of known diabetes varies inversely with family income even when education is controlled.

\section{Change in prevalence among black Americans}

Although there has been a general increase in the prevalence of known diabetes over the past 22 years, the percent increase in both the number and the rate of known diabetes has been greater for black persons than for white persons. From 1963 to 1985 , the number of white persons with known diabetes increased by $21 / 2$ times (table 5 ), and the rate increased twofold (table 6). During this same 22-year period, there was a fourfold increase in the number of black Americans with known diabetes (table 5), and there was a threefold increase in the rate (table 6).

Among black Americans, the change in the prevalence of known diabetes from 1963 to 1985 varied slightly by age (table 6). Black individuals under age 45 had the smallest increase; those 45-64 years of age, a slightly greater increase; and those 65 years and over, the greatest increase. The change in prevalence among black persons differs from the change among white persons, for whom less variation by age is seen.

Perhaps the most interesting finding that can be gleaned from the data in table 6 is the fact that only in the past 15 years has the overall ratio of the black and white rates of known diabetes clearly exceeded 1.0. Moreover, during the 1963-68 time period, when the relative frequency of known diabetes for black persons was similar to that for white persons, there were offsetting trends among males and females. Throughout the 22year period for which data are shown in table 6, black females had higher observed rates of known diabetes than white females had.

For males, however, the reverse was true. During the period 1963-67, black males had lower rates of known diabetes than white males had. Not until 1975 is the observed rate for all black males slightly higher than the observed rate for all white males.

Age variations in this crossover pattern, as well as the timing of the crossover, are difficult to assess, however, for two reasons-the lack of precision in the estimates for black males and the lack of individual-year data for the period 1969-72. Nonetheless, it appears that the rates for black males in their middle years converged with those for middle-aged white males around 1964, and the rates for younger and older black males appear to have converged with those for similarly aged white males in the late 1960's.

\section{Concluding remarks}

In this brief report, black-white differentials in the prevalence of known diabetes in the United States are documented. Information showing that the change in the relative frequency of known diabetes in the United States over the past 22 years

Table 4. Age-adjusted average annual number of persons 17 years and over with known diabetes per 1,000 population, by education of individual, race, and selected geographic characteristics: United States, 1979-81

[Data are based on annual one-third subsamples of National Health Interview Survey household interviews of the civilian noninstitutionalized population]

\begin{tabular}{|c|c|c|c|c|c|c|c|c|c|}
\hline \multirow[b]{3}{*}{ Characteristic } & \multicolumn{9}{|c|}{ Education of individual } \\
\hline & \multicolumn{3}{|c|}{ All years of education } & \multicolumn{3}{|c|}{ Less than 12 years } & \multicolumn{3}{|c|}{12 years or more } \\
\hline & $\begin{array}{c}\text { All } \\
\text { races }\end{array}$ & White & Black & $\begin{array}{c}\text { All } \\
\text { races }\end{array}$ & White & Black & $\stackrel{A l l}{\text { races }^{1}}$ & White & Black \\
\hline & \multicolumn{9}{|c|}{ Age-adjusted ${ }^{2}$ number of persons with known diabetes per 1,000 population } \\
\hline Total $^{3}$ & 33.3 & 31.0 & 55.3 & 44.1 & 40.5 & 66.1 & 26.4 & 25.3 & 39.6 \\
\hline \multicolumn{10}{|l|}{ SMSA $^{4}$ location of residence } \\
\hline 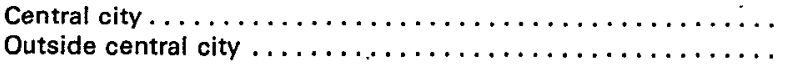 & $\begin{array}{l}36.5 \\
30.4\end{array}$ & $\begin{array}{l}30.5 \\
30.1\end{array}$ & $\begin{array}{l}61.3 \\
39.0\end{array}$ & $\begin{array}{l}49.0 \\
40.6\end{array}$ & $\begin{array}{l}40.6 \\
39.7\end{array}$ & $\begin{array}{l}74.6 \\
48.5\end{array}$ & $\begin{array}{l}28.4 \\
25.5\end{array}$ & $\begin{array}{l}25.0 \\
25.4\end{array}$ & $\begin{array}{l}44.6 \\
28.2\end{array}$ \\
\hline \multicolumn{10}{|l|}{ Region } \\
\hline 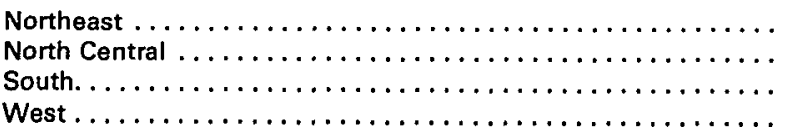 & $\begin{array}{l}31.8 \\
33.1 \\
37.4 \\
28.3\end{array}$ & $\begin{array}{l}30.4 \\
31.0 \\
34.1 \\
26.5\end{array}$ & $\begin{array}{l}53.1 \\
59.3 \\
53.8 \\
59.2\end{array}$ & $\begin{array}{l}41.4 \\
42.8 \\
49.5 \\
37.0\end{array}$ & $\begin{array}{l}38.5 \\
38.6 \\
45.4 \\
36.0\end{array}$ & $\begin{array}{l}69.1 \\
76.8 \\
63.9 \\
54.8\end{array}$ & $\begin{array}{l}25.2 \\
27.8 \\
27.5 \\
24.2\end{array}$ & $\begin{array}{l}24.7 \\
26.8 \\
26.5 \\
22.2\end{array}$ & $\begin{array}{l}36.0 \\
45.3 \\
33.0 \\
48.5\end{array}$ \\
\hline
\end{tabular}

${ }^{1}$ Includes all other races not shown in separate categories.

2 Age adjusted by the direct method to the 1979-81 civilian noninstitutionalized population of persons 17 years and over using 3 age groups.

3 Includes persons residing outside standard metropolitan statistical areas.

${ }^{4}$ SMSA $=$ standard metropolitan statistical area.

SOURCE: National Center for Health Statistics: Computed by the Division of Epidemiology and Health Promotion from $1979-81$ National Health Interview Survey data provided by the Division of Health Interview Statistics. 

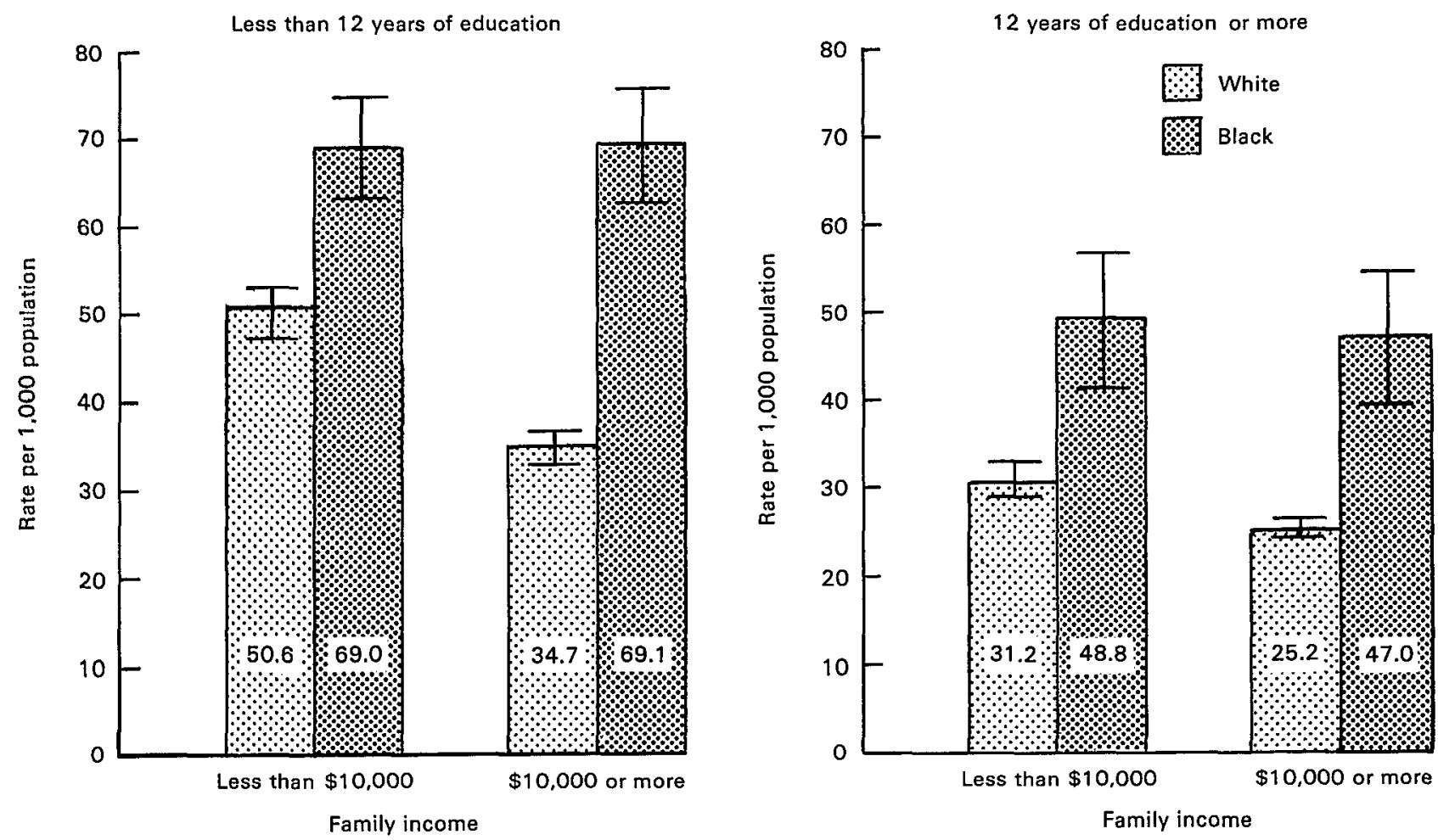

${ }^{1}$ Age adjusted by the direct method to the 1979-81 civilian noninstitutionalized population 17 years and over using 3 age groups.

NOTE: Confidence intervals are the rate plus or minus the standard error of the rate.

SOURCE: National Center for Health Statistics: Computed by the Division of Epidemiology and Health Promotion from $1979-81$ National Health Interview Survey data provided by the Division of Health Interview Statistics.

Figuro. Average age-adjusted ${ }^{1}$ number of known diabetes per 1,000 persons 17 years and over, by race, family income, and education of individual: United States, 1979-81

has been greater for black than for white Americans is also presented. So far as we know, the crossover in black-white rates of known diabetes among males, which took place during the period 1968-75, is identified here for the first time. A number of questions requiring further study are raised by these findings.

Why are the rates of known diabetes higher for black persons than for white persons? The differential does not appear to be a result simply of age and other sociodemographic differences between white and black individuals. The black subpopulation is actually younger than the white subpopulation. Were it not for this fact, black-white differentials in rates of known diabetes would be even larger than those currently observed. Moreover, irrespective of which sociodemographic category one examines, the rate of known diabetes for the group is generally higher for black than for white individuals. If sociodemographic factors do not account for the higher rate of known diabetes among black individuals, what does?

A frequent answer is that black persons are more likely than white persons to have non-insulin-dependent diabetes, for which persistent obesity is a major risk factor. ${ }^{9}$ Black persons, particularly females, are more likely than white persons to be obese and are therefore at greater risk of becoming diabetic. Researchers who have examined this interpretation have generally found that obesity does indeed play a major role in the etiology of non-insulin-dependent diabetes among black Amer- icans. ${ }^{7}$ However, because of limitations of past studies of obesity as a risk factor for non-insulin-dependent diabetes, ${ }^{14}$ better studies of black Americans' risks of becoming diabetic are clearly needed.

What is the explanation for the change in the prevalence of known diabetes among black Americans over the past 22 years? This particular change is part of a long-term increase in the prevalence of known diabetes in the general U.S. population that has extended over the past 50 years. Although a definitive study of the reasons for this secular trend has yet to be undertaken, explorations of the reasons for the overall trend ${ }^{15,16}$ shed some light on the change in the prevalence among black Americans.

The prevalence of known diabetes at the end of a year reflects both the number of new cases of diabetes identified during the year and the number of previously diagnosed cases that have survived to the end of the year. There are some data to support the view that identification of new diabetes cases was the major reason for the increase in the prevalence of known diabetes during the 1960's but that improvements in survivorship have been the major factor for the increase during the past 12 years. The confluence of aggressive screening, greater medical care access, and better methods of detection appears to be the major source of new cases of known diabetes during the 1960's. Because cardiovascular diseases are major causes of death among diabetics, improvements in survivorship 
Table 5. Number of persons with known diabetes, by sex, race, age, and selected time periods: United States, $1963-85$

[Data are based on household interviews of the civilian noninstitutionalized population]

\begin{tabular}{|c|c|c|c|c|c|c|c|c|c|}
\hline \multirow[b]{2}{*}{ Age and time period' } & \multicolumn{3}{|c|}{ Both sexes } & \multicolumn{3}{|c|}{ Male } & \multicolumn{3}{|c|}{ Female } \\
\hline & $\underset{\text { races }^{2}}{A / l}$ & White & Black & $\begin{array}{c}A / / \\
\text { races }^{2}\end{array}$ & White & Black & $\begin{array}{c}A \| l \\
\text { races }^{2}\end{array}$ & White & Black \\
\hline All ages & \multicolumn{9}{|c|}{ Number of persons with known diabetes in thousands } \\
\hline  & $\begin{array}{l}2,101 \\
2,313 \\
2,385 \\
2,772 \\
3,091 \\
3,175 \\
4,191 \\
4,780 \\
4,377 \\
5,429 \\
5,870\end{array}$ & $\begin{array}{l}1,856 \\
2,030 \\
2,076 \\
2,453 \\
2,703 \\
2,781 \\
3,570 \\
4,040 \\
3,724 \\
4,512 \\
4,751\end{array}$ & $\begin{array}{r}228 \\
256 \\
277 \\
304 \\
355 \\
372 \\
585 \\
704 \\
599 \\
834 \\
1,015\end{array}$ & $\begin{array}{r}930 \\
964 \\
996 \\
1,190 \\
1,273 \\
1,343 \\
1,620 \\
2,028 \\
1,871 \\
2,357 \\
2,474\end{array}$ & $\begin{array}{r}853 \\
885 \\
903 \\
1,085 \\
1,145 \\
1,202 \\
1,446 \\
1,763 \\
1,605 \\
2,011 \\
2,080\end{array}$ & $\begin{array}{r}70 \\
69 \\
79 \\
93 \\
115 \\
133 \\
166 \\
248 \\
233 \\
305 \\
357\end{array}$ & $\begin{array}{l}1,171 \\
1,349 \\
1,389 \\
1,583 \\
1,818 \\
1,832 \\
2,571 \\
2,752 \\
3,117 \\
3,072 \\
3,396\end{array}$ & $\begin{array}{l}1,003 \\
1,144 \\
1,173 \\
1,368 \\
1,558 \\
1,579 \\
2,124 \\
2,277 \\
2,119 \\
2,501 \\
2,671\end{array}$ & $\begin{array}{l}158 \\
187 \\
198 \\
211 \\
240 \\
239 \\
420 \\
456 \\
366 \\
529 \\
658\end{array}$ \\
\hline \multicolumn{10}{|l|}{ Under 45 years } \\
\hline  & $\begin{array}{r}356 \\
435 \\
415 \\
507 \\
571 \\
569 \\
789 \\
847 \\
790 \\
900 \\
1,076\end{array}$ & $\begin{array}{l}312 \\
370 \\
361 \\
453 \\
491 \\
486 \\
650 \\
697 \\
662 \\
730 \\
899\end{array}$ & $\begin{array}{r}41 \\
53 \\
42 \\
51 \\
71 \\
80 \\
133 \\
146 \\
115 \\
163 \\
165\end{array}$ & $\begin{array}{l}181 \\
178 \\
196 \\
244 \\
218 \\
263 \\
295 \\
362 \\
318 \\
370 \\
467\end{array}$ & $\begin{array}{l}167 \\
163 \\
176 \\
226 \\
199 \\
237 \\
254 \\
302 \\
275 \\
302 \\
401\end{array}$ & $\begin{array}{r}* 14 \\
* 12 \\
* 13 \\
* 16 \\
* 19 \\
* 26 \\
39 \\
58 \\
39 \\
65 \\
63\end{array}$ & $\begin{array}{l}175 \\
256 \\
219 \\
263 \\
352 \\
306 \\
494 \\
485 \\
472 \\
530 \\
609\end{array}$ & $\begin{array}{l}144 \\
206 \\
186 \\
228 \\
291 \\
249 \\
395 \\
395 \\
386 \\
429 \\
499\end{array}$ & $\begin{array}{r}* 28 \\
41 \\
* 29 \\
36 \\
52 \\
54 \\
94 \\
88 \\
76 \\
99 \\
102\end{array}$ \\
\hline \multicolumn{10}{|l|}{$45-64$ years } \\
\hline  & $\begin{array}{r}942 \\
992 \\
1,033 \\
1,174 \\
1,339 \\
1,371 \\
1,813 \\
2,166 \\
1,895 \\
2,406 \\
2,439\end{array}$ & $\begin{array}{r}804 \\
850 \\
881 \\
1,007 \\
1,134 \\
1,173 \\
1,518 \\
1,801 \\
1,576 \\
1,942 \\
1,887\end{array}$ & $\begin{array}{l}131 \\
129 \\
140 \\
163 \\
181 \\
178 \\
282 \\
349 \\
300 \\
408 \\
492\end{array}$ & $\begin{array}{r}439 \\
432 \\
431 \\
551 \\
628 \\
564 \\
819 \\
983 \\
881 \\
1,146 \\
1,107\end{array}$ & $\begin{array}{l}395 \\
392 \\
389 \\
495 \\
553 \\
497 \\
731 \\
859 \\
752 \\
954 \\
886\end{array}$ & $\begin{array}{r}40 \\
* 34 \\
42 \\
54 \\
63 \\
59 \\
86 \\
114 \\
113 \\
164 \\
198\end{array}$ & $\begin{array}{r}503 \\
560 \\
602 \\
623 \\
710 \\
807 \\
993 \\
1,183 \\
1,014 \\
1,259 \\
1,332\end{array}$ & $\begin{array}{r}409 \\
457 \\
492 \\
512 \\
582 \\
677 \\
787 \\
942 \\
824 \\
988 \\
1.001\end{array}$ & $\begin{array}{r}91 \\
94 \\
97 \\
109 \\
118 \\
118 \\
196 \\
236 \\
187 \\
244 \\
293\end{array}$ \\
\hline \multicolumn{10}{|l|}{65 years and over } \\
\hline 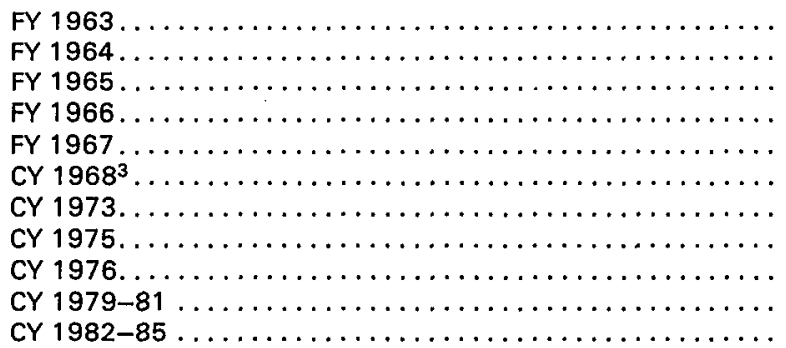 & $\begin{array}{r}803 \\
887 \\
938 \\
1,091 \\
1,181 \\
1,236 \\
1,589 \\
1,767 \\
1,692 \\
2,123 \\
2,445\end{array}$ & $\begin{array}{r}740 \\
811 \\
834 \\
993 \\
1,078 \\
1,122 \\
1,402 \\
1,542 \\
1,486 \\
1,839 \\
2,037\end{array}$ & $\begin{array}{r}56 \\
75 \\
95 \\
90 \\
103 \\
114 \\
171 \\
209 \\
184 \\
262 \\
376\end{array}$ & $\begin{array}{l}310 \\
354 \\
369 \\
394 \\
426 \\
516 \\
506 \\
684 \\
673 \\
840 \\
939\end{array}$ & $\begin{array}{l}291 \\
330 \\
339 \\
365 \\
393 \\
468 \\
461 \\
602 \\
578 \\
755 \\
819\end{array}$ & $\begin{array}{r}* 16 \\
* 23 \\
* 23 \\
* 24 \\
* 33 \\
48 \\
40 \\
76 \\
81 \\
76 \\
109\end{array}$ & $\begin{array}{r}493 \\
533 \\
568 \\
696 \\
755 \\
725 \\
1,083 \\
1,083 \\
1,019 \\
1,283 \\
1,505\end{array}$ & $\begin{array}{r}449 \\
481 \\
495 \\
628 \\
684 \\
653 \\
941 \\
940 \\
908 \\
1,084 \\
1,218\end{array}$ & $\begin{array}{r}39 \\
52 \\
72 \\
66 \\
70 \\
67 \\
130 \\
133 \\
104 \\
186 \\
267\end{array}$ \\
\hline
\end{tabular}

${ }^{1} \mathrm{CY}=$ calendar year. $\mathrm{FY}=$ fiscal year.

${ }^{2}$ Includes all other races not shown as separate categories.

${ }^{3} \mathrm{CY} 1968$ data are for July-December only.

SOURCE: National Center for Health Statistics: Computed by the Division of Epidemiology and Health Promotion from $1963-85$ National Health Interview Suney data provided by the Division of Health Interview Statistics.

among diabetics during the past 15 years are clearly linked to the general decline in coronary heart disease and stroke mortality since 1970. Evaluation of how adequately this interpretation of the general increase in the prevalence of known diabetes accounts for the change in the prevalence among black Americans has yet to be conducted. Also in need of study is the extent to which the crossover in black and white rates of known diabetes (which appears to have taken place among males during the period 1968-73) is explainable within this same framework.

To what extent does the change in the prevalence of known diabetes among black Americans mean that a reservoir of un- 
Table 6. Number of persons with known diabetes per 1,000 population, by sex, race, age, and selected time periods: United States, $1963-85$ [Data are based on household interviews of the civilian noninstitutionalized population]

\begin{tabular}{|c|c|c|c|c|c|c|c|c|c|}
\hline \multirow[b]{2}{*}{ Age and time period ${ }^{1}$} & \multicolumn{3}{|c|}{ Both sexes } & \multicolumn{3}{|c|}{ Male } & \multicolumn{3}{|c|}{ Female } \\
\hline & $\begin{array}{c}A / l \\
\text { races }\end{array}$ & White & Black & $\begin{array}{c}A / / \\
\text { races }^{2}\end{array}$ & White & Black & $\begin{array}{c}\text { All } \\
\text { races }^{2}\end{array}$ & White & Black \\
\hline All ages & \multicolumn{9}{|c|}{ Number of persons with known diabetes per 1,000 population } \\
\hline 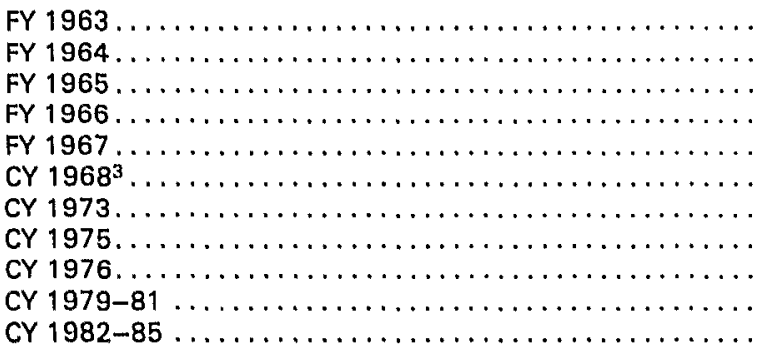 & $\begin{array}{l}11.5 \\
12.5 \\
12.7 \\
14.5 \\
16.1 \\
12.6 \\
20.4 \\
22.9 \\
20.8 \\
24.7 \\
25.5\end{array}$ & $\begin{array}{l}11.5 \\
12.4 \\
12.5 \\
14.6 \\
16.0 \\
12.6 \\
19.9 \\
22.2 \\
20.4 \\
23.8 \\
24.1\end{array}$ & $\begin{array}{l}11.7 \\
12.7 \\
13.8 \\
14.6 \\
16.9 \\
13.1 \\
24.7 \\
28.9 \\
24.1 \\
32.3 \\
36.9\end{array}$ & $\begin{array}{l}10.5 \\
10.7 \\
10.9 \\
12.9 \\
13.7 \\
11.0 \\
16.3 \\
20.1 \\
18.4 \\
22.2 \\
22.2\end{array}$ & $\begin{array}{l}10.9 \\
11.1 \\
11.2 \\
13.3 \\
14.0 \\
11.2 \\
16.6 \\
20.0 \\
18.1 \\
21.9 \\
21.8\end{array}$ & $\begin{array}{r}7.6 \\
7.2 \\
8.3 \\
9.4 \\
11.6 \\
9.8 \\
15.0 \\
21.8 \\
20.1 \\
25.5 \\
28.0\end{array}$ & $\begin{array}{l}12.4 \\
14.1 \\
14.3 \\
16.1 \\
18.3 \\
14.0 \\
24.1 \\
25.4 \\
23.0 \\
27.0 \\
28.5\end{array}$ & $\begin{array}{l}12.6 \\
13.6 \\
13.7 \\
15.8 \\
17.8 \\
13.8 \\
22.9 \\
24.3 \\
22.5 \\
25.6 \\
26.4\end{array}$ & $\begin{array}{l}15.5 \\
17.6 \\
18.8 \\
19.2 \\
21.6 \\
16.0 \\
33.2 \\
35.0 \\
27.6 \\
38.1 \\
44.6\end{array}$ \\
\hline \multicolumn{10}{|l|}{ Under 45 years } \\
\hline 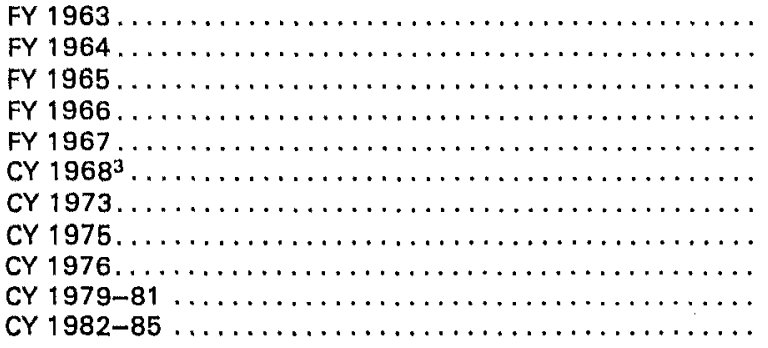 & $\begin{array}{l}2.8 \\
3.3 \\
3.1 \\
3.8 \\
4.2 \\
3.1 \\
5.5 \\
5.9 \\
5.4 \\
5.9 \\
6.6\end{array}$ & $\begin{array}{l}2.8 \\
3.2 \\
3.1 \\
3.9 \\
4.2 \\
3.1 \\
5.3 \\
5.6 \\
5.3 \\
5.7 \\
6.6\end{array}$ & $\begin{array}{l}2.8 \\
3.4 \\
2.7 \\
3.2 \\
4.4 \\
3.5 \\
7.3 \\
7.9 \\
6.1 \\
8.3 \\
7.7\end{array}$ & $\begin{array}{l}2.9 \\
2.8 \\
3.0 \\
3.7 \\
3.3 \\
2.9 \\
4.2 \\
5.1 \\
4.4 \\
4.9 \\
5.8\end{array}$ & $\begin{array}{l}3.0 \\
2.9 \\
3.1 \\
3.9 \\
3.5 \\
3.0 \\
4.2 \\
4.9 \\
4.4 \\
4.7 \\
5.9\end{array}$ & $\begin{array}{l}* 1.9 \\
{ }^{*} 1.6 \\
{ }^{*} 1.8 \\
{ }^{*} 2.0 \\
{ }^{*} 2.5 \\
{ }^{*} 2.4 \\
4.5 \\
6.6 \\
4.3 \\
6.9 \\
6.2\end{array}$ & $\begin{array}{l}2.7 \\
3.8 \\
3.2 \\
3.8 \\
5.1 \\
3.3 \\
6.8 \\
6.6 \\
6.4 \\
6.9 \\
7.5\end{array}$ & $\begin{array}{l}2.5 \\
3.6 \\
3.2 \\
3.8 \\
4.9 \\
3.1 \\
6.4 \\
6.4 \\
6.2 \\
6.6 \\
7.3\end{array}$ & $\begin{array}{r}* 3.5 \\
5.0 \\
* 3.6 \\
4.2 \\
6.1 \\
4.6 \\
9.8 \\
9.0 \\
7.7 \\
9.4 \\
9.1\end{array}$ \\
\hline \multicolumn{10}{|l|}{$45-64$ years } \\
\hline 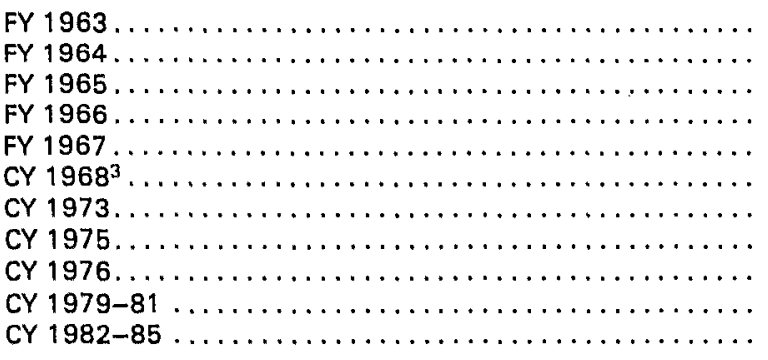 & $\begin{array}{l}25.5 \\
26.4 \\
27.0 \\
30.3 \\
34.1 \\
28.5 \\
42.5 \\
50.3 \\
43.8 \\
55.0 \\
55.1\end{array}$ & $\begin{array}{l}24.0 \\
24.9 \\
25.5 \\
28.7 \\
31.9 \\
26.9 \\
39.6 \\
46.6 \\
40.7 \\
49.8 \\
48.3\end{array}$ & $\begin{array}{r}40.6 \\
38.8 \\
42.2 \\
47.7 \\
53.7 \\
42.9 \\
72.5 \\
87.3 \\
73.0 \\
100.8 \\
114.9\end{array}$ & $\begin{array}{l}24.6 \\
23.8 \\
23.4 \\
29.7 \\
33.4 \\
24.4 \\
40.6 \\
47.8 \\
42.7 \\
55.0 \\
52.6\end{array}$ & $\begin{array}{l}24.4 \\
23.8 \\
23.3 \\
29.3 \\
32.4 \\
23.7 \\
40.1 \\
46.4 \\
40.5 \\
51.1 \\
47.3\end{array}$ & $\begin{array}{r}26.2 \\
* 22.0 \\
27.5 \\
34.0 \\
40.6 \\
31.0 \\
48.8 \\
62.6 \\
60.3 \\
89.7 \\
104.9\end{array}$ & $\begin{array}{l}26.3 \\
28.8 \\
30.4 \\
31.0 \\
34.7 \\
32.3 \\
44.4 \\
52.5 \\
44.8 \\
55.1 \\
57.3\end{array}$ & $\begin{array}{l}23.7 \\
26.0 \\
27.5 \\
28.2 \\
31.5 \\
30.0 \\
39.2 \\
46.7 \\
40.8 \\
48.7 \\
49.2\end{array}$ & $\begin{array}{r}53.4 \\
53.7 \\
54.9 \\
59.7 \\
64.9 \\
53.2 \\
92.2 \\
107.9 \\
83.7 \\
109.9 \\
122.8\end{array}$ \\
\hline \multicolumn{10}{|l|}{65 years and over } \\
\hline 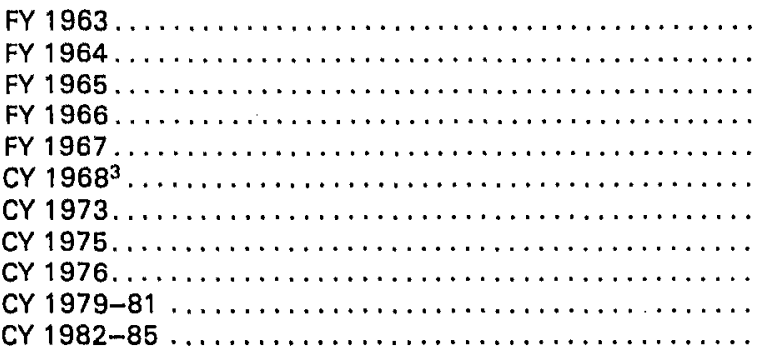 & $\begin{array}{l}47.6 \\
52.1 \\
54.2 \\
62.1 \\
66.1 \\
60.2 \\
78.5 \\
83.0 \\
77.6 \\
88.3 \\
93.3\end{array}$ & $\begin{array}{l}47.6 \\
51.6 \\
52.3 \\
61.3 \\
65.5 \\
59.3 \\
75.9 \\
79.7 \\
75.2 \\
84.4 \\
86.0\end{array}$ & $\begin{array}{r}46.2 \\
61.5 \\
77.2 \\
69.6 \\
77.4 \\
74.6 \\
101.8 \\
114.3 \\
97.9 \\
131.7 \\
172.9\end{array}$ & $\begin{array}{l}41.3 \\
46.9 \\
48.6 \\
51.3 \\
54.9 \\
58.3 \\
60.3 \\
77.9 \\
75.1 \\
85.1 \\
87.7\end{array}$ & $\begin{array}{l}42.1 \\
47.6 \\
48.4 \\
51.6 \\
55.2 \\
57.8 \\
60.5 \\
75.9 \\
71.4 \\
84.5 \\
84.5\end{array}$ & $\begin{array}{r}* 29.8 \\
{ }^{*} 41.8 \\
{ }^{*} 42.5 \\
*^{*} 42.0 \\
{ }^{*} 55.0 \\
68.6 \\
56.6 \\
96.6 \\
100.9 \\
93.8 \\
125.6\end{array}$ & $\begin{array}{l}52.7 \\
56.2 \\
58.7 \\
70.4 \\
74.8 \\
61.6 \\
91.3 \\
86.6 \\
79.4 \\
90.6 \\
97.2\end{array}$ & $\begin{array}{l}51.9 \\
54.8 \\
55.3 \\
68.7 \\
73.4 \\
60.5 \\
86.7 \\
82.4 \\
77.8 \\
84.3 \\
87.0\end{array}$ & $\begin{array}{r}59.6 \\
77.7 \\
104.4 \\
91.7 \\
95.6 \\
79.5 \\
135.1 \\
127.7 \\
95.7 \\
158.0 \\
204.1\end{array}$ \\
\hline
\end{tabular}

${ }^{1} \mathrm{CY}=$ calendar year. $\mathrm{FY}=$ fiscal year.

${ }^{2}$ Includes all other races not shown as separate categories.

${ }^{3} \mathrm{CY} 1968$ data are for July-December only.

SOURCE: National Center for Health Statistics: Computed by the Division of Epidemiology and Health Promotion from 1963-85 National Health Interview Survey data provided by the Division of Health Interview Statistics.

diagnosed diabetes is slowly being exhausted by improved methods of detection? If one views the "true" prevalence of diabetes in the population at any point in time as the sum of persons with diagnosed diabetes and persons with undiagnosed diabetes, it is conceivable that a change in the prevalence of diagnosed diabetes could take place even though there was no change in the "true" prevalence. From this perspective, a change in the prevalence of known diabetes means simply that a change has occurred in the ratio of diagnosed to undiagnosed diabetes. Has something akin to this happened historically among black Americans?

A definitive answer to this question would require histor- 
ically comparable, replicated measurements of the prevalence of diagnosed and undiagnosed diabetes among black Americans for the past 22 years. Unfortunately, the estimates of diagnosed and undiagnosed diabetes from the second National Health and Nutrition Examination Survey (NHANES II) are the first estimates available for a national probability sample of U.S. adults. Moreover, earlier estimates ${ }^{17}$ are not comparable with the NHANES II assessments in at least three respects: (1) Earlier estimates of the total prevalence of diabetes were based on selected community samples, (2) the methods of ascertainment used were less sensitive than the 2-hour 75-gram oral glucose tolerance test used in the NHANES II survey, and (3) estimates were never published for different racial categories of the population.

From earlier estimates of the total prevalence of diabetes in selected communities, it appears that the ratio of diagnosed to undiagnosed diabetes was about 1 to $1 .{ }^{17}$ The NHANES II estimates for 1976-80 indicate that, among black Americans, there was about one undiagnosed diabetic for every diagnosed one. ${ }^{18}$ Therefore, it would appear that the change in the prevalence of known diabetes among black Americans over the past 22 years is not simply the result of a change in the ratio of diagnosed to undiagnosed diabetes. It is conceivable, of course, that the less sensitive methods of case ascertainment used in the earlier surveys produced underestimates of the ratio of diagnosed to undiagnosed diabetes. If the ratio of diagnosed to undiagnosed diabetes among black people was historically much higher than the ratio found in NHANES II, then observed trends in known diabetes among black Americans might reflect, to some extent, a change in the ratio. Further study of this issue is clearly needed. It is hoped that data that shed some light on stability or change in this ratio during the period 1976-93 can be collected in the 1988-93 National Health and Nutrition Examination Survey, which is currently being planned.

Readers interested in pursuing these and related questions about diabetes among black Americans might well begin by consulting summaries of extant information that have recently appeared in government and other publications. ${ }^{8.10 .19-21}$ 


\section{References}

${ }^{1}$ Public Health Service, Division of Public Health Methods, L. E. Bollo: Diabetes reported in interviews, United States, July 1957-June 1959. Health Statistics From the U.S. National Health Survey. Series B, No. 21. Pub. No. (PHS) 584-B21. Washington. U.S. Government Printing Office, Sept. 1960.

${ }^{2}$ National Center for Health Statistics, M. L. Bauer: Characteristics of persons with diabetes, United States, July 1964-June 1965. Vital and Health Statistics. Series 10, No. 40. (PHS) Pub. No. 1000. Public Health Service. Washington. U.S. Government Printing Office, Oct. 1967.

${ }^{3}$ National Center for Health Statistics, G. Scott: Prevalence of chronic conditions of the genitourinary, nervous, endocrine, metabolic, and blood and blood-forming systems and of other selected chronic conditions, United States, 1973. Vital and Health Statistics. Series 10, No. 109. DHEW Pub. No. (HRA) 77-1536. Health Resources Administration. Washington. U.S. Government Printing Office, Mar. 1977.

${ }^{4}$ National Institutes of Health: Report of the National Commission on Diabetes to the Congress of the United States, Volume III, Reports of Committees, Subcommittees, and Workgroups, Part 1, Scope and Impact on Diabetes (1). DHEW Pub. No. (NIH) 77-1021. Bethesda, Md., 1977.

${ }^{5}$ National Institute of Arthritis, Metabolism, and Digestive Diseases, National Diabetes Data Group: Diabetes Data, Compiled 1977. DHEW Pub. No. (NIH) 78-1468. National Institutes of Health. Washington. U.S. Government Printing Office, 1978.

"National Center for Health Statistics, T. F. Drury, M. Harris, and L. E. Lipsett: Prevalence and management of diabetes. Health, United States, 1981. DHHS Pub. No. (PHS) 82-1232. Public Health Service. Washington. U.S. Government Printing Office, Dec. 1981, pp. 25-31.

${ }^{7}$ G. S. Bonham and D. W. Brock: The relationship of diabetes with race, sex and obesity. Am. J. Clin. Nutr. 41:776-783, 1985.

${ }^{8}$ National Institutes of Health, J. M. Roseman: Diabetes in Black Americans, in Diabetes in America. NIH Pub. No. 85-1468. Washington. U.S. Government Printing Office, Aug. 1985, pp. VIII-1-24.

${ }^{9}$ U.S. Department of Health and Human Services: Report of the Secretary's Task Force on Black and Minority Health, Volume I, Executive Summary. Washington. U.S. Government Printing Office, Aug. 1985, pp. 107-128.

${ }^{10}$ U.S. Department of Health and Human Services: Report of the Secretary's Task Force on Black and Minority Health, Volume VII, Chemical Dependency and Diabetes, Report of the Subcommittee on Diabetes. Washington. U.S. Government Printing Office, Jan. 1986, pp. 214-229.

${ }^{11}$ National Center for Health Statistics, S. S. Jack and P. W. Ries: Current estimates from the Health Interview Survey, United States, 1979. Vital and Health Statistics. Series 10, No. 136. DHHS Pub. No. (PHS) 81-1564. Public Health Service. Washington. U.S. Government Printing Office, Apr. 1981.
${ }^{12}$ National Center for Health Statistics, S. S. Jack: Current estimates from the National Health Interview Survey, United States, 1980. Vital and Health Statistics. Series 10, No. 139. DHHS Pub. No. (PHS) 82-1567. Public Health Service. Washington. U.S. Government Printing Office, Dec. 1981.

${ }^{13}$ National Center for Health Statistics, B. Bloom: Current estimates from the National Health Interview Survey, United States, 1981. Vital and Health Statistics. Series 10, No. 141. DHHS Pub. No. (PHS) 82-1569. Public Health Service. Washington. U.S. Government Printing Office, Oct. 1982.

${ }^{14} \mathrm{~K}$. Flegal: Epidemiological Studies on the Relationship Between Diabetes and Obesity in Human Populations: A Review of the Literature. Report prepared for National Institutes of Health. Ithaca, N.Y. Cornell University, Division of Nutritional Sciences, Mar. 1979.

${ }^{15}$ M. Harris: The Prevalence of Diagnosed Diabetes, Undiagnosed Diabetes, and Impaired Glucose Tolerance in the United States, in J. S. Melish, J. Hanna, and S. Baba, eds., Genetic Environmental Interaction in Diabetes Mellitus. Amsterdam. Excerpta Medica, 1981, pp. 71-76.

${ }^{16}$ National Center for Health Statistics, T. F. Drury: The change in the prevalence of known diabetes in the United States: 1935-85. Advance Data From Vital and Health Statistics. Public Health Service. Hyattsville, Md. To be published.

${ }^{17}$ Q. R. Remein: A current estimate of the prevalence of diabetes mellitus in the United States. Ann. N.Y. Acad. Sci. 82:229-235, 1959.

${ }^{18}$ National Institutes of Health, M. I. Harris: Prevalence of Noninsulin-Dependent Diabetes and Impaired Glucose Tolerance, in Diabetes in America. NIH Pub. No. 85-1468. Washington. U.S. Government Printing Office, Aug. 1985, pp. VI-1-39.

${ }^{19}$ National Center for Health Statistics, T. F. Drury and A. L. Powell: Prevalence, impact, and demography of known diabetes in the United States, Advance Data From Vital and Health Statistics. No. 114. DHHS Pub. No. (PHS) 86-1250. Public Health Service. Hyattsville, Md., Feb. 12, 1986.

${ }^{20} \mathrm{~A}$. S. Krolewski and J. H. Warram: Epidemiology of Diabetes Mellitus, in A. Marble et al., eds., Joslin's Diabetes Mellitus, 12 th ed. Philadelphia. Lea and Febiger, 1985, pp. 12-42.

${ }^{21}$ National Center for Health Statistics, W. C. Hadden and M. I. Harris: Prevalence of diagnosed diabetes, undiagnosed diabetes, and impaired glucose tolerance in adults 20-74 years of age. Vital and Health Statistics. Series 11, No. 237. DHHS Pub. No. 87-1687. Public Health Service. Washington. U.S. Government Printing Office, Feb. 1987.

${ }^{22}$ National Center for Health Statistics, J. G. Collins: Prevalence of selected chronic conditions, United States, 1979-81. Vital and Health Statistics. Series 10, No. 155. DHHS Pub. No. (PHS) 86-1583. Public Health Service. Washington. U.S. Govemment Printing Office, July 1986. 


\section{Technical notes}

The data presented in all tables in this report were derived from household interviews of the National Health Interview Survey. These interviews were conducted in a probability sample of the civilian noninstitutionalized population of the United States. From July 1963 through June 1968, information on the prevalence of known diabetes was collected each year from the full NHIS sample. After 1968, however, similar information was collected from the full NHIS sample only in 1973,1975 , and 1976. During the period 1978-81, information on the prevalence of known diabetes was collected in NHIS from a one-third subsample of respondents. Since 1982, however, this information has been obtained from only a onesixth subsample of respondents.

Because the estimates shown in this report are based on a sample of the population, they are subject to sampling error. In table I, standard errors for 1979-81 estimates of the number of persons with known diabetes (shown in tables 1 and 2 of this report) are given. Standard errors appropriate for percents, including the percent of persons with known diabetes during 1979-81 (which can be derived from the data shown in table 2) are given in table II. Standard errors for data prior to 1979, as well as standard errors for 1982 and later data, are available in published sources. ${ }^{1-3,22}$ The standard errors for the age-adjusted rates shown in table 3 of this report are not available elsewhere and have therefore been shown in that table.

Estimates of diabetes based on household reports are limited to conditions individuals know about and are willing to report. Moreover, although it is widely recognized that the term "diabetes mellitus" refers to a heterogeneous group of disorders characterized by glucose intolerance, it is not possible to routinely tabulate National Health Interview Survey diabetes data to identify different types of diabetics. Because it

NOTE: A list of references follows the text.
Table I. Standard errors of estimates of aggregates based on one-third subsample of National Health Interview Survey, 1979-81

\begin{tabular}{|c|c|}
\hline Size of estimates in thousands & $\begin{array}{l}\text { Standard error } \\
\text { in thousands }\end{array}$ \\
\hline 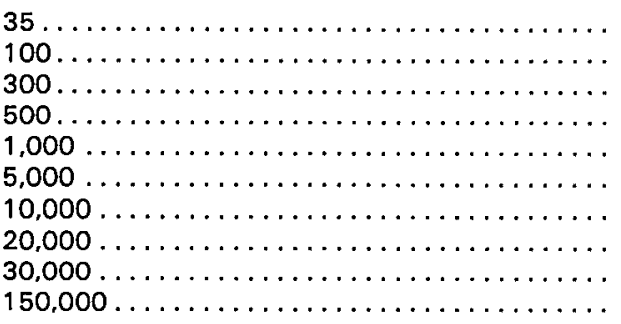 & $\begin{array}{r}11 \\
18 \\
31 \\
40 \\
57 \\
125 \\
174 \\
237 \\
278 \\
393\end{array}$ \\
\hline
\end{tabular}

Table II. Standard errors, expressed in percentage points, of estimated percents based on one-third subsample of National Health Interview Survey, 1979-81

\begin{tabular}{|c|c|c|c|c|c|}
\hline \multirow[b]{2}{*}{$\begin{array}{c}\text { Base of percents } \\
\text { in thousands }\end{array}$} & \multicolumn{5}{|c|}{ Estimated percents } \\
\hline & $\begin{array}{l}2 \text { or } \\
98\end{array}$ & $\begin{array}{l}5 \text { or } \\
95\end{array}$ & $\begin{array}{l}10 \text { or } \\
90\end{array}$ & $\begin{array}{c}30 \text { or } \\
70\end{array}$ & 50 \\
\hline 200 . & 1.8 & 2.8 & 3.8 & 5.9 & 6.4 \\
\hline $300 \ldots \ldots \ldots \ldots \ldots \ldots$ & 1.4 & 2.0 & 3.1 & 4.8 & 5.2 \\
\hline $400 \ldots \ldots \ldots \ldots \ldots$ & 1.2 & 1.9 & 2.7 & 4.1 & 4.5 \\
\hline $500 \ldots \ldots \ldots \ldots \ldots$ & 1.1 & 1.8 & 2.4 & 3.7 & 4.0 \\
\hline $1,000 \ldots$ & 0.8 & 1.2 & 1.7 & 2.6 & 2.9 \\
\hline 2,000 & 0.6 & 0.9 & 1.2 & 1.8 & 2.0 \\
\hline 5,000 & 0.4 & 0.6 & 0.8 & 1.1 & 1.3 \\
\hline$\ldots \ldots \ldots \ldots \ldots$ & 0.3 & 0.4 & 0.5 & 0.8 & 0.9 \\
\hline $20,000 \ldots \ldots \ldots \ldots \ldots$ & 0.2 & 0.3 & 0.4 & 0.6 & 0.6 \\
\hline $30,000 \ldots$ & 0.1 & 0.2 & 0.3 & 0.5 & 0.5 \\
\hline $50,000 \ldots \ldots \ldots \ldots$ & 0.1 & 0.2 & 0.2 & 0.4 & 0.4 \\
\hline
\end{tabular}

is estimated that general population samples contain mainly non-insulin-dependent diabetics, one should be cautious in generalizing the descriptions in this report to insulin-dependent diabetics. 


\section{Symbois}

.. Data not available

... Category not applicable

- Quantity zero

0.0 Quantity more than zero but less than 0.05

Z Quantity more than zero but less than 500 where numbers are rounded to thousands

* Figure does not meet standard of reliability or precision

\# $\quad$ Figure suppressed to comply with confidentiality requirements 
Recent Issues of Advance Data From Vital and Health Statistics

No. 129. Visits to Office-Based Physicians by Hispanic Persons: United States, 1980-81 (Issued February 17, 1987)

No. 128. National Ambulatory Medical Care Survey: 1985 Summary (Issued January 23, 1987)

No. 127. 1985 Summary: National Hospital Discharge Survey (Issued September 25, 1986)
No. 126. Health Promotion Data for the 1990 Objectives, Estimates From the National Health Interview Survey of Health Promotion and Disease Prevention: United States, 1985 (Issued September 19, 1986)

No. 125. Aging in the Eighties, Impaired Senses for Sound and Light in Persons Age 65 Years and Over, Preliminary Data From the Supplement on Aging to the National Health Interview Survey: United States, January-June 1984 (Issued September 19, 1986)

\section{Suggested citation}

National Center for Health Statistics, T. F. Drury and A. L. Powell: Prevalence of known diabetes among black Americans. Advance Data From Vital and Health Statistics. No. 130. DHHS Pub. No. (PHS) 87-1250. Public Health Service. Hyattsville, Md., July 31, 1987.

Copyright Information

This report may be reprinted without further permission.

\section{U.S. DEPARTMENT OF HEALTH AND \\ HUMAN SERVICES \\ Public Health Service \\ Natıonal Center for Health Statistics \\ 3700 East-West Highway \\ Hyattsville, Maryland 20782}

OFFICIAL BUSINESS

PENALTY FOR PRIVATE USE, $\$ 300$

To receive this publication regularly, contact the National Center for Health Statistics by calling 301 436-8500

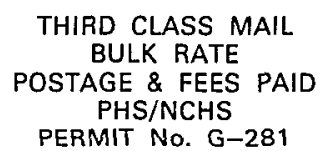

